\title{
Effect of Nitrogen and Phosphorus Fertilizer Rates on Yield and Yield Components of Barley (Hordeum Vugarae L.) Varieties at Damot Gale District, Wolaita Zone, Ethiopia
}

\author{
Mesfin Kassa ${ }^{1}$, Zemach Sorsa ${ }^{2}$ \\ ${ }^{1}$ Soil science, Wolaita Sodo University, College of Agriculture, Wolaita Sodo, Ethiopia \\ ${ }^{2}$ Plant Breeding, Wolaita Sodo University, College of Agriculture, Wolaita Sodo, Ethiopia
}

Email address:

mesfine2004@gmail.com (M. Kassa),zemachsorsa@yahoo.com (Z. Sorsa)

To cite this article:

Mesfin Kassa, Zemach Sorsa. Effect of Nitrogen and Phosphorus Fertilizer Rates on Yield and Yield Components of Barley (Hordeum Vugarae L.) Varieties at Damot Gale District, Wolaita Zone, Ethiopia. American Journal of Agriculture and Forestry. Vol. 3, No. 6, 2015, pp. 271-275. doi: 10.11648/j.ajaf.20150306.15

\begin{abstract}
A field experiment was conducted at Damot Gale District, Wolaita Zone, SNNPRS to evaluate the response of barely varieties to nitrogen and phosphorus fertilizer application since the response varies from location to location due to several factors. Thus, there is a need to determine specific nitrogen and phosphorus fertilizer requirement of specific variety. The barley varieties (HB1370 and Shage) were used as test crop and the experiment contained factorial combination of four levels of N/P $\left(0 / 0,23 / 10,46 / 20,69 / 30 \mathrm{~kg} \mathrm{ha}^{-1}\right)$ and was laid out in randomized complete block design with three replications. The results from this study indicated that nitrogen and phosphorus fertilizer showed no significant effect on number of days to heading while number of fertile tillers, total biomass and yield were significantly increased by application of nitrogen and phosphorus. However, the effects of nitrogen and phosphorus were significant $(\mathrm{P}<0.05)$ on plant height, spike length, number of seeds per spike and grain yield. In general, grain yield tended to be higher under NP $69 / 30 \mathrm{~kg} \mathrm{ha}^{-1}$ treatment $(2.02 \mathrm{t} / \mathrm{ha})$. In contrast, the lowest grain yield $(0.86 \mathrm{t} / \mathrm{ha})$ was obtained from $0 / 0 \mathrm{NP}$ treatment, although the interaction effects of nitrogen and phosphorus were significant on treatments with varieties and balanced amount of nitrogen and phosphorus. The future studies should articulate towards the studies involving more varieties, multi-location and additional rates of nitrogen and phosphorus applications, under diverse management practices such as research and farmer's field's conditions, which may facilitate finetuning of fertilizer recommendations.
\end{abstract}

Keywords: Fertilizer, Phenology, Growth, Yield

\section{Introduction}

Barley (Hordeum vulgarae L.) is cultivated in every region of Ethiopia implicating its wide ecological plasticity and physiological amplitude (Lakew et al., 1996). Barley ranks fourth in worldwide production of all cereals (FAO, 2004). In Ethiopia, barley is ranked fifth of all cereals, based on area of production, but third based on yield per unit area (CSA, 2004).Within Ethiopia, the highest levels of barley consumption occur in highlands where it is widely cultivated, accounting for the bulk of the total crop harvest (Kiros, 1993). In Ethiopia, barley covers $10 \%$ of the land under crop cultivation with a yield of $1.2 \mathrm{tha}^{-1}$ (CACC, 2002), where as the potential yield goes up to $6 \mathrm{t} / \mathrm{ha}$ on experimental plots (Berhane Lakew, Habtamu et al., 2014; Hailu Gebre and
Fekadu Alemayehu, 1996). Several a biotic and biotic factors have contributed to this low productivity, such as poor crop management practices; the use of low yielding cultivars; the limited availability of the very few improved cultivars released; weeds, insects and diseases; and the inherently low yield potential of the prevalent local varieties (Asfaw Negassa et al., 1997; Hailu Gebre and Fekadu Alemayehu, 1996; ChilotYirga, Fekadu Alemayehu and Woldeyesus Sinebo, 1998; Woldeyesus Sinebo andChilot Yirga, 2002).

This low productivity is mainly due to traditional methods of production and poor soil fertility. Poor soil fertility and low $\mathrm{pH}$ are among the most important constraints that threaten barley production in Ethiopia. Since the major barley producing areas of the country are mainly located in the highlands, severe soil erosion and lack of appropriate soil conservation practices in the past have resulted in soils with 
low fertility and $\mathrm{pH}$ (Grando and McPherson, 2005). Particularly deficiency of nitrogen and phosphorus is the main factor that severely reduces the yield of barely. According to Desta Beyene (1987), although soil fertility status is dynamic and variable from locality to locality, and it is difficult to end up with a blanket recommendation invariably, some soil amendment studies were undertaken at different times and places. Even though several researches have been conducted on high land areas of Ethiopia, like Bale, Wello, North Shewa and some parts of Arsi region have bimodal pattern of rainfall permitting production of barley twice a year both on summer and winter seasons (Alemayehu, 1994). The soils that are mostly under cereal cultivation in the study area are Nitisols and Vertisols (Solomon, 2006). Barley yields are increased also by phosphorus and potash fertilizers on some soils (Bulman and Smith, 1993). In addition to fertilizer rates, soil acidity also affects the productivity of the land by affecting availability of nutrients and hindering the activity of microorganisms. Also nitrogen is commonly the most limiting nutrient for crop production in the major world's agricultural areas and therefore adoption of good $\mathrm{N}$ management strategies often result in large economic benefits to farmers. Among the plant nutrients, nitrogen plays a very important role in crop productivity (Zapata \& Cleenput, 1986; Ahmad, 1999; Miao et al., 2006; Oikeh et al., 2007; Assefa and Chekole, 2015, Worku et al., 2007). Soil fertility is one of the major production constraints in the Southern region of Ethiopia (Getahun and Tenaw, 1990). The various factors accounting for the poor soil fertility include topography, soil erosion, deforestation, population pressure, and continuous cultivation without proper soil fertility maintenance (Tenaw, 1996). This area under barley cultivation is about 123000 ha and production is estimated to be about $150000 \mathrm{t}$, with a mean yield of $1.2 \mathrm{t} /$ ha in the main cropping season (MOA, 2000). In the Wolaita zone, where the experiment was conducted, barley is the fourth most important cereal after maize, sorghum and tef in area coverage (BOA, 1998). Despite its importance and cultivation of the yield and productivity of barley in the country, Region and in the Wolaita zone have low yields compared with its potential. Among the major constraints on increased production of barley are poor soil fertility, limited supply of production inputs, low prices for the produce, and undeveloped markets (Hailu Gebre, 1978). Furthermore, phosphorus has a high nutritional value, with high concentrations of nitrogen, and potassium, while the contamination by heavy metals and other toxic substances are very low (Asghar et al,. 2006).There was no research conducted concerning fertilizers rates as a result of this fact, the farmers rely on traditional practices and local cultivars. Most of the farmers in experiment site do not use NP combination above the recommended rate. Therefore, there is a need to study the effect of different NP rates on the yield and yield components of barely with the following specific objectives:

- To examine the effect of NP fertilizer on yield and yield components of barley varieties.

- To evaluate barley varieties in the study area

\section{Materials and Methods}

\subsection{Description of the Study Site}

This study was carried out at Damote Gale, Wolaita zone, which is found in the Southern Nations Nationalities and Peoples Regional State. It is located $375 \mathrm{~km}$ south of Addis Ababa. The study area is located on latitude of $6055^{\prime}$ '36.1" $\mathrm{N}$ and longitude of 370 50'12.1" E, with an elevation of 2110 m.a.s.l.

\subsection{Treatments and Experimental Design}

The treatments consisted of combination of four levels of phosphorus and nitrogen (0/0,10/23, 20/46 and 30/69 kgha1) and barely varieties (HB-1307, and Shage).The twenty four treatment combinations were replicated three times in factorial RCBD design. A plot size of $3 \mathrm{~m}^{2}$ with $20 \mathrm{~cm}$ spacing between rows and spacing of $1 \mathrm{~m}$ between blocks and $0.5 \mathrm{~m}$ between plots were used. Nitrogen was applied in the form of urea, while $\mathrm{P}$ was applied in the form of triple supper phosphate. Nitrogen was applied in split, half during sowing and half at booting stage.

\subsection{Data Collection and Analysis}

The data were collected as Days to heading, plant height, spike length, number of seeds per spike, number of tiller per plots, number of non fertile tillers per plots, thousand seed weight, and total above ground biomass.

\subsection{Soil Sampling and Analysis}

For soil analysis, before planting soil samples were randomly taken from the experimental site at a depth of $30 \mathrm{~cm}$ using an auger and the samples were mixed thoroughly to produce one representative composite sample of $1 \mathrm{~kg}$. The soil samples were air-dried and ground to pass 2 and $0.5 \mathrm{~mm}$ (for total N) sieves. All samples were analyzed following standard laboratory procedures as outlined by Sahlemedhin and Taye (2000). Organic carbon and total N contents of the soil were determined following the wet combustion method of Walkley and Black, and wet digestion procedure of Kjeldahl method, respectively. The available P content of the soil was determined following Olsen method. Soil texture was analyzed by Bouyoucos hydrometer method. The cations exchange capacity (CEC) of the soil was determined following the $1 \mathrm{~N}$ ammonium acetate $(\mathrm{pH} 7)$ method. $\mathrm{Ca}$ and $\mathrm{Mg}$ contents were measured by using EDTA titration, the $\mathrm{pH}$ (1:2.5 solid: liquid ratio) of the soils was measured in water using $\mathrm{pH}$ meter with glass-calomel combination electrode.

\subsection{Statistical Analysis}

The data collected on different parameters were statistically analyzed using PROC ANOVA function of SAS program. After performing ANOVA the differences between the treatment means were compared by LSD test at 5\% level of significance. 


\section{Result and Discussion}

\subsection{Physical and Chemical Properties of the Soil}

Soil analysis before sowing showed that soil $\mathrm{pH}$, available $\mathrm{P}, \mathrm{CEC}$ and Total $\mathrm{N}$ found in the range of slightly acidic based on Herrera (2005) classification, however a result of some soil physical and chemical properties of the experimental site were showed that medium. The soil analysis result indicated that texture of the soil was clay loam and $\mathrm{pH}$ of the soil was 6.0 slightly acidic, this range is suitable for different crops have different requirements but the optimum $\mathrm{pH}$ range for barley is $6.0-7.0$. Therefore, the $\mathrm{pH}$ of soil is suitable for barley (CLDB, 2001). Other soil chemical properties were total Nitrogen (TN \%) is rated by Havlin et al. (1999) as very low $(<0.1)$, low $(0.1$ to 0.15$)$, medium (0.15 to 0.25$)$, and high $(>0.25)$. According to Olsen et al. (1954) rating, $\mathrm{P}(\mathrm{mg} \mathrm{Kg}-1)$ content is: $(<3)$ very low, $(4$ to 7$)$ low, (8 to 11) medium, $(>11)$ high. Then available $\mathrm{P}$ at the site was within medium and low respectively. It might be because of this that some growth and yield components responded better to $\mathrm{P}$ than to $\mathrm{N}$. In line with this $\mathrm{M}$. Osundwa et al. (2013) reported liming of acidic soils reduces the $P$ sorption thus increasing its availabilities. However, over all residual soil $\mathrm{P}$ of the treatments were categorized under very low status

\subsection{Effects of Nitrogen and Phosphorus Fertilizer Rates on Plant Growth and Yield Parameter}

Plant height was significantly affected by different rates of NP application (Table 1.) In line with this, Rashid et al (2007) indicated that plant height was linearly increased with increasing levels of NP fertilization. The maximum plant height $(86.02 \mathrm{~cm})$ was recorded from application of $69 / 30 \mathrm{~kg}$ NP ha-1 and zero application of NP result the minimum plant height, which was significantly lower than the effect of other rates. Such increment of plant height along with increase of $\mathrm{NP}$ rate might be related to the effect of nitrogen which promotes vegetative growth as other growth factors are in conjunction with it. This result is in line with the report of Wakene et al. (2014) who stated that plant height of barely was increase with increasing rates of NP from $0 / 0$ to $69 / 30 \mathrm{~kg}$ ha-1. The experiment by Rashid et al. (2007) was conducted in arid zone which received $182 \mathrm{~mm}$ rain fall during the growing period. Most of the time, arid zone soils are salt affected soils in which nutrient availability is influenced and application of $\mathrm{P}$ slightly increased plant height. The maximum plant height of $83.1 \mathrm{~cm}$ was recorded at the highest NP rates of $69 / 30 \mathrm{~kg}$ ha-1 and the minimum plant height of $61.3 \mathrm{~cm}$ was recorded in NP rates of $0 / 0 \mathrm{~kg}$ ha- 1 . Similarly, Taye Bekele et al. (1996) and Woldeyesus Sinebo (2005) reported that the yield of barley increase with increasing N/P fertilizer application at many locations.

Interaction between varieties and Plant height was no significant (Table 1). Maximum days (100 days) were recorded from plants which received $0 \mathrm{~kg} \mathrm{~N} / \mathrm{P} \mathrm{ha}^{-1}$. Similar results were reported by Kernich and Halloran (1996), who observed that nitrogen fertilizer considerably influenced duration of the pre-anthesis period and spike in barley. The probable reason might be that optimum NP supply played an essential role in plant growth and development. Maqsood et al. (2001), Kenbaev \& Sade (2002), Salwa et al. (2005), Soylu et al. (2005), Arif et al. (2006) and Pervez et al. (2009) reported significant increase in plant height of wheat with application of nitrogen. In case of NP levels, maximum no of tillers (51.9) was produced with the application of $69 / 30 \mathrm{~kg}$ NP ha ${ }^{-1}$ when compared with other treatments (Table1). The probable reason might be that optimum nitrogen availability plays an essential role in plant growth whereas low or very high dose of nitrogen caused reduction in above ground vegetative growth of plant. Increase in the number of tillers of wheat due to $\mathrm{N}$ application was also reported by Rajput et al. (1993) and Ahmad (1999).Non significant $(\mathrm{P}<0.05)$ differences were observed in two verities, spike length, grains spike-1, 1000 grain weight, grain yield, straw yield, biological yield, harvest index, grain and straw $\mathrm{N}$ due to various levels of $\mathrm{N}$ and varieties (Table 2). Cantero et al., (1995), Le Gouis et al., (1999) and Oweis et al., (1999) observed similar results for grains spike-1 in barley was significantly increased with increasing $\mathrm{N}$ fertilization as reported by Moselhy \& Zahran (2002). They further revealed that application of nitrogen fertilizer significantly increased spike length, number of grains spike-1, 1000 grain weight, grain yield and $\mathrm{N}$ uptake by the crop (Chaudhary \& Mehmood, 1998; Bakhsh et al., 1999; Wakene et al., 2014; Tilahun et al., 2000)

Both $\mathrm{N}$ and $\mathrm{P}$ significantly influenced total biomass but their interaction effect was not significant (Table 1). The highest TBM of $3.9 \mathrm{t}$ ha-1 was recorded in the treatment which received 69/30 NP kg N ha-1 though not significantly different to the TBM obtained from $0 / 0 \mathrm{NP}$ Kg N ha-1 $(2.4 \mathrm{t}$ ha-1) (Table 1). Nitrogen and phosphors increases vegetative growth of plants, especially at higher doses. Besides, the significant increase in spike length, number of seeds per spike, number of fertile tillers, non fertile tillers and grain yield by NP contributed for the significant increase in TBM. This is in agreement with Alam and Haider (2006) who indicated that increased nitrogen level increased total dry matter irrespective of cultivars. The highest TBM of $3.91 \mathrm{t}$ ha-1 was obtained from the highest level (69/30 NP kg ha-1) though not significantly different from $3.2 \mathrm{t}$ ha-1 obtained at 46/20 NP tha-1. Other authors also reported similar results from researches conducted on wheat Alcoz et al. (1993); Tilahun Geleto et al. (1996) indicating that P significantly increased TBM. On the other hand, application of NP fertilizer as well as its interaction with verities had nonsignificant effect on growth and yields components. It was increased with increasing application rates of NP up to $69 / 30$ $\mathrm{kg}$ NP ha-1. The minimum value $(52.4 \mathrm{~g})$ was obtained from application of zero NP $(\mathrm{P}<0.05)$ (Table 1$)$.

The effect of both nitrogen and phosphorus on thousand seed weight might be attributed to the positive effect of $\mathrm{N}$ and $\mathrm{P}$ on biomass production of plants. Analysis of variance showed that application of both nitrogen and phosphorus 
fertilizer had significant $(\mathrm{p}<0.05)$ interaction effect on total above ground dry mass (Table 1). Total above ground dry mass increased significantly when NP rates increased while combined with all rates of $\mathrm{P}$ but significant increase was observed when $\mathrm{N}$ rate increased from $0 \mathrm{~kg}$ ha-1 to $69 \mathrm{~kg}$ ha-1 with combination of P 0 to $30 \mathrm{~kg}$ ha- 1 . Similarly, significant increment of total above ground dry mass was observed as application rates of $\mathrm{P}$ increased and combined with all rates of N. Number of tillers per plots were not significantly to NP rates. According to this experiment, NP did not significantly affect number of tillers and infertile tillers. Maqsood et al (1999) reported that the increase in the number of fertile tillers with increasing nitrogen levels could be attributed to the well-accepted role of nitrogen in accelerating vegetative growth of plants. But, according to this experiment, the contributions of NP were also very high, it agrees with the result obtained by Prystupa et al (2004), who reported that number of productive tillers/plant was affected significantly by NP fertilizer application. The yield response of barley to NP application rates was determined for 2 years (2003-2004) in the Arjo, Gedo and Shambo highlands of Ethiopia. Results of the combined analysis of variance over 2 years showed that the mean grain yield of barley was not significantly affected by $\mathrm{NP}$, nor by $\mathrm{N} \times \mathrm{P}$ interactions at Arjo, in which the application of 10/30 kgha-1 N/P resulted in the highest mean grain yield of barley (BARC,2006). At Gedo, the grain yield of barley was significantly affected by $\mathrm{N}$ application, the application of 10 kgha- $1 \mathrm{~N}$ resulted in a better grain yield (2469 kg ha-1) than the control and other $\mathrm{N}$ rates. Nevertheless, the combined application of NP at a rate of $10 / 30 \mathrm{~kg} / \mathrm{ha}$ resulted in the highest yield .At Shambo, the grain yield of barley was significantly $(\mathrm{P}<0.05)$ affected by $\mathrm{P}$ application but not by $\mathrm{N}$ or $\mathrm{N} \times \mathrm{P}$ interactions. The application of 20/30 kgha-1 N/P doubled the barley grain yield compared with the unfertilized (BARC, 2006).

Table 1. Effect of NP fertilizer on barley yield and yield components in Damot Gela, 2014.

\begin{tabular}{|c|c|c|c|c|c|c|c|c|c|c|}
\hline Treatments & $\begin{array}{l}\text { Plant } \\
\text { height } \\
(\mathrm{cm})\end{array}$ & $\begin{array}{l}\text { Spike } \\
\text { length } \\
\text { (cm) }\end{array}$ & $\begin{array}{l}\text { No } \\
\text { seed/spike }\end{array}$ & $\begin{array}{l}\text { No of } \\
\text { Infertile } \\
\text { tillers }\end{array}$ & $\begin{array}{l}\text { No of } \\
\text { fertile } \\
\text { tillers }\end{array}$ & $\begin{array}{l}\text { Yield } \\
\text { t/ha }\end{array}$ & $\begin{array}{l}\text { Biomass } \\
\text { t/ha }\end{array}$ & $\begin{array}{l}\text { Days to } \\
\text { heading }\end{array}$ & $\begin{array}{l}\text { 1000seed } \\
\text { weight }\end{array}$ & $\begin{array}{l}\text { Harvest } \\
\text { index }\end{array}$ \\
\hline $0 / 0$ & 61.3 & 6.3 & 36.3 & 34.5 & 253.6 & 0.86 & 2.4 & 65 & 52.4 & 9.3 \\
\hline $23 / 10$ & 69.6 & 6.3 & 37.8 & 31.5 & 241.1 & 0.106 & 2.6 & 60 & 53.2 & 13.0 \\
\hline $46 / 20$ & 74.8 & 6.3 & 39.5 & 12.6 & 300.6 & 1.77 & 3.2 & 52 & 54.1 & 14.2 \\
\hline $69 / 30$ & 83.1 & 6.6 & 42.6 & 15.8 & 338.0 & 2.02 & 3.9 & 55 & 54.8 & 15.5 \\
\hline $\operatorname{LSD}(0.05)$ & 8.5 & 0.5 & 7.0 & 42.3 & 73.4 & 2.3 & 0.4 & 15.4 & 5.2 & 6.9 \\
\hline CV (\%) & 9.6 & 7.8 & 14.8 & 45.5 & 16.2 & 17.2 & 12.5 & 13.2 & 5.6 & 14.8 \\
\hline
\end{tabular}

Table 2. Interaction effects on barely varieties in Damote Gela, 2014.

\begin{tabular}{|c|c|c|c|c|c|c|c|c|}
\hline Varieties & $\begin{array}{l}\text { Plant height } \\
(\mathrm{cm})\end{array}$ & $\begin{array}{l}\text { Spike length } \\
(\mathrm{cm})\end{array}$ & No seed/spike & $\begin{array}{l}\text { No of Infertile } \\
\text { tillers }\end{array}$ & $\begin{array}{l}\text { No of fertile } \\
\text { tillers }\end{array}$ & $\begin{array}{l}\text { Yield } \\
\text { Qt/ha }\end{array}$ & $\begin{array}{l}\text { Biomass } \\
\text { t/ha }\end{array}$ & \\
\hline HB-1307 & 71.0 & 6.5 & 37.3 & 17.3 & 275.5 & 22.2 & 2.9 & NS \\
\hline Shage & 73.4 & 6.3 & 40.8 & 29.9 & 291.0 & 21.4 & 3.1 & NS \\
\hline LSD5\% & 5.8 & 0.4 & 4.9 & 29.9 & 51.9 & 0.6 & 0.3 & \\
\hline
\end{tabular}

\section{Conclusion}

Nutrient application of plants can be varied from location to location depending on different factors such as soil and other agro-ecologies. For sustainable production of crops for a particular area, specific fertilizer recommendation is very crucial. For this reason a field experiment was conducted in Damot Gale District, Ethiopia in 2013/14. The soil was clay loam with $\mathrm{pH}$ of 6 (slightly acidic). This experiment was conducted to assess the effect of $\mathrm{N}$ and $\mathrm{P}$ on yield and yield components of barley. The treatments consisted of combination of four levels of phosphorus and nitrogen $(0 / 0$, 10/23, 20/46 and 30/69 kgha-1) and barely varieties (HB1307, and Shage).The twenty four treatment combinations were replicated three times in factorial RCBD design. Many of the growth and development parameters observed responded to NP fertilization. Days to heading, number of fertile tillers and total biomass were non significantly influenced by NP application and also there is no interaction effect in verities. Other parameters, such as, plant height, number of fertile tillers, and TBM, were no significantly increased by NP rates. Therefore, N and P fertilizers are very important nutrients in limiting the growth and development of crops which has direct effect on productivity of the crops. The future studies should articulate towards and studies' involving more varies, multi-location and additional rates of $\mathrm{N}$ and $\mathrm{P}$ application, under diverse management practices, which may facilitate fine-tuning of fertilizer recommendations.

\section{References}

[1] Alemayehu Asefa, 1994. Drought stress during the belg season and selection of barley land races in the north Shewa, Ethiopia. Nile Valley and Red Sea Regional Program on cool season food legume and cereals, ICARADA/NVRSRP. Ethiopia. 209-216.

[2] Assefa Workineh Chekole. Response of Barley (Hordium vulgare L.) to Integrated Cattle Manureand Mineral Fertilizer Application in the Vertisol Areas of South Tigray, Ethiopia. Journal of Plant Sciences. Vol. 3, No. 2, 2015, pp. 71-76. doi: $10.11648 /$ j.jps.20150302.15. 
[3] Asmare Yallew, Hailemicheal Shewayirga, Assefa Alebachew \& Rahel Asrat. 1998a. Barley production practices and constraints in Meket Wereda, North Welo. pp 91-95, in: Chilot Yirga, Fekadu Alemayehu and Woldeyesus Sinebo (eds.). Barley-based Farming Systems in the Highlands of Ethiopia. Ethiopian Agricultural Research Organization, Addis Ababa, Ethiopia.

[4] Awassa Agricultural Research Centre. 2005. Progress Report of the period 2004/2005. Awassa, Ethiopia.

[5] BOA [Bureau of Agriculture]. 1998. Regional BasicInformation. Bureau of Agriculture Planning andProgramming Service, Awassa, Ethiopia.

[6] Bulman, P., and D.L Smith. 1993. Grain protein response of spring barley to high rate and post anthesis application of fertilizer nitrogen. Journal of agronomy, 85(6):11091113.

[7] Berhane Lakew, Hailu Gebre \& Fekadu Alemayehu. 1996. Barley production and research. pp $1-8$, in: Hailu Gebre and J.A.G. van Leur (eds.). Barley Research in Ethiopia: Past Work and Future Prospects. Proceedings of the 1st Barley Research Review Workshop, 16-19 October 1993, Addis Ababa. IAR/ICARDA, Addis Ababa, Ethiopia.

[8] Chilot Yirga, Berhane Lakew \& Fekadu Alemayehu. 2002. On-farm evaluation of food barley production packages in the highlands of Wolemera and Degem, Ethiopia. pp 176187, in: Gemechu Kenini, Yohannes Gojjam, Kiflu Bedane, Chilot Yirga and Asgelil Dibabe (eds.). Towards Farmers' Participatory Research: Attempt and Achievements in the Central Highlands of Ethiopia. Proceedings of a Client-Oriented Research Evaluation Workshop, Holetta Agricultural Research Centre, Holetta, Ethiopia.

[9] CACC (Central Agricultural Census Commission). 2002.

[10] (Hordeum vulgare L.) at Bore District, Southern Oromia Report on the Preliminary Results of Area, Production and Yield of Temporary Crops (Meher Season, Private Peasant Holdings) Part I. Addis Ababa, Ethiopia. 200 p.

[11] CLDB (Canada land development branch). 2001. Cropfertilization guide. New Nouveau Brunswick, Canada.

[12] Habtamu A., Heluf G., Bobe B., Enyew A. Fertility Status of Soils under Different Land uses at Wujiraba Watershed, North-Western Highlands of Ethiopia. Agriculture, Forestry and Fisheries. Vol. 3, No. 5, 2014, pp. 410-419. doi: $10.11648 /$ j.aff.20140305.24

[13] Hailu Gebre and J.L. Van, 1996. Barley Research in Ethiopia: Past Work and Future Prospects. Proceeding of the first barley research review workshop IAR/ICARADA. Addis Ababa, Ethiopia.
[14] Havlin JL, JD Beaton, SL Tisdale, WL Nelson (1999). Soilfertility and fertilizers: An introduction to nutrient management. Prentice Hall, New York, 499p.

[15] Kiros Meles, 1993. Studies on barley scald (Rhynchesporium secalis (oud.) and evaluation of barley line for resistance to the disease in Ethiopia. An MSc Thesis presented to Alemaya University of Agriculture. $71 \mathrm{p}$.

[16] Lakew, B., Gebre, H. and Alemayehu, F. 1996. Barley production and research in Ethiopia. In Barley Research in Ethiopia: Past Work and Future Prospects, H. Gebre and J. van leur (Eds.). Proceedings of the first barley research review workshop, 16-19 October 1993. Addis Ababa. IAR/ICARDA.

[17] MOA [Ministry of Agriculture]. 2000. Management information systems and data processing service. Ministry of Agriculture Bulletin No. 1 (August 2000).MOA, Addis Ababa, Ethiopia.

[18] M. Osundwa, J. Okalebo, W. Ngetich, J. Ochuodho, C. Othieno, B. Langat and V. Omenyo. Influence of agricultural lime on soil properties and wheat (Triticum aestivum L.) yield on acidic soils of Uasin Gishu County, Kenya. American Journal of Experimental Agriculture, 2013, 3(4): pp 806-823.

[19] Olsen SR, CV Cole, FS Watanabe, LA Dean 1954).Estimation of available phosphorus in soils by extraction with sodium bicarbonate. USA Circular. 939: 119.

[20] Rashid A, Khan UK, Khan DJ (2007). Comparative Effect of Varieties and Fertilizer Levels on Barley (Hordeum vulgare). ISSN Online: 1814-9596, Pakistan.

[21] Solomon Yilma, 2006. Characteristics, classification and agricultural potentials of soils of Gonde microcatchment, Arsi highlands, Ethiopia. A thesis presented to the school of graduate studies of Haramaya University. Haramaya. $74 \mathrm{p}$.

[22] Wakene Tigre, Walelign Worku, Wassie Haile. Effects of Nitrogen and Phosphorus Fertilizer Levels on Growth and Development of Barley (Hordeum vulgare L.) at Bore District, Southern Oromia, Ethiopia. American Journal of Life Sciences. Vol. 2, No. 5, 2014, pp. 260-266. doi: 10.11648/j.ajls.20140205.12.

[23] Woldeyesus Sinebo \& Chilot Yirga. 2002. Participatory client-orientation of research in lowinput cropping systems of Ethiopia. pp 27-43, in: Gemechu Kenini, Yohannes Gojjam, Kiflu Bedane, Chilot Yirga and Asgelil Dibabe (eds.). Towards Farmers' Participatory Research: Attempts and Achievements in the Central Highlands of Ethiopia. Proceedings of a Client-Oriented Research Evaluation Workshop. Holetta Agricultural Research Centre, Holetta, Ethiopia. 